\title{
ESTIMATION OF GENE EFFECTS THROUGH GENERATION MEAN ANALYSIS IN ELITE RICE (Oryza sativa L.) CROSSES
}

\author{
N Lingaiah ${ }^{1}$, Ch Surender Raju ${ }^{2}$, K. Radhika ${ }^{3}$, N. Sarla ${ }^{4}$, V Venkanna ${ }^{5}$, \\ D. Vishnu Vardhan Reddy ${ }^{6}$
}

\footnotetext{
${ }^{1}$ Agricultural College, Mulugu Road, Warangal-506007, PJTSAU, Telangana, India

${ }^{2}$ Rice Research Institute, Rajendranagar, Hyderabad-30

${ }^{3}$ Department of Seed Science and Technology, Advanced post graduate Centre, Lam, Guntur, Andhra Paradesh 522034

${ }^{4}$ Division of Crop Improvement, ICAR- IIRR (ICAR-Indian Institute Of Rice Research), Rajendranagar, Hyderabad-30

${ }^{5}$ Agricultural College, Aswaraopet, Kothagudem-Bhadradri (Dist) Telanganan state 507301

${ }^{6}$ Prof Jayashankar Telangana State Agricultural University (PJTSAU), Rajendranagar, Hyderabad-30
}

Received - October 16, 2019; Revision - December 27, 2019; Accepted - February 01, 2020

Available Online - February 25, 2020

DOI: http://dx.doi.org/10.18006/2020.8(1).15.20

\section{KEYWORDS \\ Rice \\ Generation mean analysis \\ $\chi^{2}$ test}

Joint scale test

Epistasis

Additive and dominance

\section{ABSTRACT}

An experimental was carried out to study the gene action governing yield and its attributing traits for three crosses utilizing five diversified rice genotypes at Regional Agricultural Research Station, Warangal. The experimental material consisted of six generations $\left(\mathrm{P}_{1}, \mathrm{P}_{2}, \mathrm{~F}_{1}, \mathrm{~F}_{2}, \mathrm{BC}_{1}\right.$ and $\left.\mathrm{BC}_{2}\right)$ obtained from three crosses using five parents laid out in a randomized block design with three replications to study the generation mean analysis for yield and yield attributing characters viz., days to $50 \%$ flowering (days), plant height $(\mathrm{cm})$, total number of productive tillers per plant (Nos.), panicle length $(\mathrm{cm})$, number of grains per panicle (Nos.), test weight (gm) and grain yield per plant (gm). The Generation mean analysis indicated the presence of epistasis in expression of grain yield and its components. The interaction was of duplicate epistasis, therefore, in addition to the main genetic effects, ([d], [h] components, the interaction components were also taken into consideration to develop the breeding strategy. Prevalence of significant additive effects in the crosses MTU1010 x NH-686, RP-Bio-5478185 x NH-787 indicated effectiveness of direct selection for yield improvement. The interaction components are highly variable; therefore, a cross and trait specific breeding strategy i.e direct selection and development of pure lines are appropriate for yield improvement.
* Corresponding author

E-mail: nlrashi80@gmail.com (N Lingaiah)

Peer review under responsibility of Journal of Experimental Biology and Agricultural Sciences.

Production and Hosting by Horizon Publisher India [HPI] (http://www.horizonpublisherindia.in/).

All rights reserved.
All the articles published by Journal of Experimental Biology and Agricultural Sciences are licensed under a Creative Commons Attribution-NonCommercial 4.0 International License Based on a work at www.jebas.org.

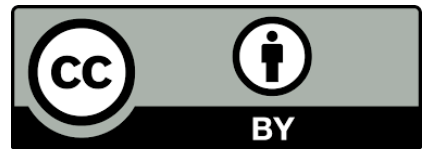




\section{Introduction}

The success of any breeding programme lies in thorough understanding of the genetic architecture of the genotypes and the nature of the gene action. Generation mean analysis is used to estimate the component variance which provides information about the predominant type of gene action for the different characters (Hayman, 1958; Jinks \& Jones, 1958). Generation mean analysis provides information about the type of interallelic interaction besides genetic components of variance. Generation mean analysis is a tool for designing the most appropriate breeding approaches to develop crop varieties with desired traits and is commonly used in studies on the inheritance of quantitative traits (Uzokwe et al., 2017). This type of analysis provides information on the relative importance of the average effects of the genes viz., additive effects (d), dominance deviations (h) and effects due to nonallelic gene interactions viz., additive $\mathrm{x}$ additive (i), additive $\mathrm{x}$ dominance ( $\mathrm{j}$ ) and dominance $\mathrm{x}$ dominance (1) (Subbalaxmi et al., 2016; Uzokwe et al., 2017). The objective of this study was to understand the gene action of yield and its attributing characters in rice through generation mean analysis which helps in deciding a suitable procedure for improvement of various traits.

\section{Materials and Methods}

Five rice genotypes viz. MTU 1010, WGL-32100, RP-Bio5478-185, NH-686 and RP-Bio-5478-166 were selected based on contrasting characters viz., grain size and flowering duration and developed material $\left(\mathrm{F}_{1}, \mathrm{~F}_{2}, \mathrm{BC}_{1}\right.$ and $\left.\mathrm{BC}_{2}\right)$ for 3 independent crosses (MTU $1010 \mathrm{X} \mathrm{NH}-686$, WGL-32100 X RP-Bio-5478-166 and RP-Bio-5478 -185 X NH-686) during Kharif, 2014, rabi 2014-15 and Kharif, 2015 at Regional Agricultural Research Station, Warangal district of India as given below to study the presence of non allelic interactions through generation mean analysis for grain yield and its attributing characteristics.

Variation for kernel dimensions such as long slender $\mathrm{x}$ short bold (cross 1), medium slender x short bold (cross 2) and short bold $\mathrm{x}$ short bold (cross 3) and flowering duration was considered as criteria for selection of parents for generation mean analysis. The entire work (crossing and evaluation) was taken up at Regional Agricultural Research Station, (RARS), Warangal, PJTSAU.

During Kharif, 2014 crossing programme was taken up to get $F_{1}$ seed from these three crosses. During Rabi 2014-15, these $F_{1}$ 's were raised to get $F_{2}$ seed and simultaneous these $F_{1}$ 's were mated with their respective parents to get $\mathrm{BC}_{1}$ and $\mathrm{BC}_{2}$ seed of three crosses in the same season. Parents were also selfed to ensure $100 \%$ genetic purity. Thus, seed of six basic generations, $\mathrm{P}_{1}, \mathrm{P}_{2}, \mathrm{~F}_{1}, \mathrm{~F}_{2}, \mathrm{BC}_{1}$ and $\mathrm{BC}_{2}$ was in hand for these three crosses at the end of the season Rabi 2014-15.

During Kharif, $2015 \mathrm{P}_{1}, \mathrm{P}_{2}, \mathrm{~F}_{1}, \mathrm{~F}_{2}, \mathrm{BC}_{1}$ and $\mathrm{BC}_{2}$ of 3 crosses were raised to study the generation mean analysis. The material was sown in randomized block design with three replications. Recommended cultural practices were adopted. The total number of population raised in each replication was 30 for parents and $F_{1}, 60$ for back cross generations and 300 for $F_{2}$.

\section{Results and Discussion}

Generation mean analysis was carried out using 6 generations means $\left(\mathrm{P}_{1}, \mathrm{P}_{2}, \mathrm{~F}_{1}, \mathrm{~F}_{2}, \mathrm{BC}_{1} \& \mathrm{BC}_{2}\right)$. Adequacy of additive dominance model was tested by using A, B, C, D scales of Mather (1949) and also further confirmed by the Joint scaling test of Cavalli (1952). Results of current study also confirmed the workability of Joint Scaling test. In the present study, scaling test for three crosses as shown in Table 1,2 and 3 indicated the presence of non-allelic interaction owing to significance of any

Table 1 Scaling tests of generation means for the cross MTU-1010 x NH-686 for different traits

\begin{tabular}{|c|c|c|c|c|c|}
\hline \multirow[b]{3}{*}{ S.No } & \multicolumn{5}{|c|}{ MTU-1010 x NH-686 } \\
\hline & Character & & & & \\
\hline & Yield traits & A & B & $\mathrm{C}$ & $\mathrm{D}$ \\
\hline 1 & Days to 50 per cent flowering & $13.00^{* *} \pm 0.59$ & $10.33^{* * \pm 0} 0.93$ & $22.00 * * \pm 1.97$ & $-0.66 \mathrm{NS} \pm 0.91$ \\
\hline 2 & Plant height $(\mathrm{cm})$ & $3.22 * \pm 1.49$ & $-1.97 \mathrm{NS} \pm 1.48$ & $12.47 * * \pm 2.65$ & $5.61 \pm 1.24$ \\
\hline 3 & No. of productive tillers/plant & $-7.34 * * \pm 1.12$ & $-6.63 * * \pm 0.67$ & $-8.87 * * \pm 1.48$ & $2.55 * * \pm 0.25$ \\
\hline 4 & Panicle length $(\mathrm{cm})$ & $3.03 * * \pm 0.85$ & $3.24 * * \pm 0.64$ & $7.76 * * \pm 1.34$ & $0.74 \mathrm{NS} \pm 0.68$ \\
\hline 5 & No. of grains/ panicle & $56.44 * * \pm 7.06$ & $57.48 * * \pm 4.32$ & $128.29 * * \pm 6.81$ & $7.18 \mathrm{NS} \pm 4.13$ \\
\hline 6 & 1000 grain weight $(\mathrm{g})$ & $-5.15 * * \pm 0.67$ & $-11.35 * * \pm 0.29$ & $-18.66 * * \pm 1.34$ & $-1.07 \mathrm{NS} \pm 0.59$ \\
\hline 7 & Grain yield/plant (g) & $-8.86 * * \pm 1.26$ & $-7.63 * * \pm 0.76$ & $-13.45 * * \pm 1.49$ & $1.52 * \pm 0.73$ \\
\hline
\end{tabular}

The values indicated \pm corresponds to Standard error of mean 
Table 2 Scaling tests of generation means for the cross WGL-32100 X RP-Bio- 5478-166 for different traits

\begin{tabular}{|c|l|c|c|c|c|} 
& \multicolumn{5}{|c|}{ WGL-32100 X RP-Bio-5478-166 } \\
S. No & \multicolumn{1}{|c|}{$\begin{array}{c}\text { Characteristics } \\
\text { Yield traits }\end{array}$} & A & B & C & D \\
\hline 1 & Days to 50 per cent flowering & $3.66^{* *} \pm 0.60$ & $4.33^{* *} \pm 0.69$ & $12.66^{* *} \pm 2.65$ & $2.33 \mathrm{NS} \pm 1.33$ \\
\hline 2 & Plant height $(\mathrm{cm})$ & $75.36^{* *} \pm 1.14$ & $94.98^{* *} \pm 1.68$ & $151.29^{* *} \pm 6.41$ & $-9.52^{* *} \pm 3.16$ \\
\hline 3 & No. of productive tillers/plant & $-5.66^{* *} \pm 0.46$ & $-1.33^{*} \pm 0.55$ & $1.66 \mathrm{NS} \pm 1.46$ & $4.33^{* *} \pm 0.78$ \\
\hline 4 & Panicle length $(\mathrm{cm})$ & $2.61^{*} \pm 1.13$ & $0.95 \mathrm{NS} \pm 0.95$ & $4.78^{*} \pm 2.04$ & $0.61 \mathrm{NS} \pm 0.76$ \\
\hline 5 & No. of grains/ panicle & $-142.17^{* *} \pm 5.19$ & $-115.10^{* *} \pm 3.06$ & $-233.68^{* *} \pm 58.62$ & $11.79^{* *} \pm 2.59$ \\
\hline 6 & 1000 grain weight (g) & $0.96 \mathrm{NS} \pm 0.57$ & $-1.32^{* *} \pm 0.47$ & $2.33 \mathrm{NS} \pm 1.32$ & $1.34^{*} \pm 0.58$ \\
\hline 7 & Grain yield/plant $(\mathrm{g})$ & $-7.10^{* *} \pm 0.57$ & $-10.69^{* *} \pm 0.74$ & $-17.76^{* *} \pm 1.07$ & $0.01 \mathrm{NS} \pm 0.55$ \\
\hline
\end{tabular}

The values indicated \pm corresponds to Standard error of mean

Table 3 Scaling tests of generation means for the cross RP-Bio-5478 -185 x NH- 686 for different traits

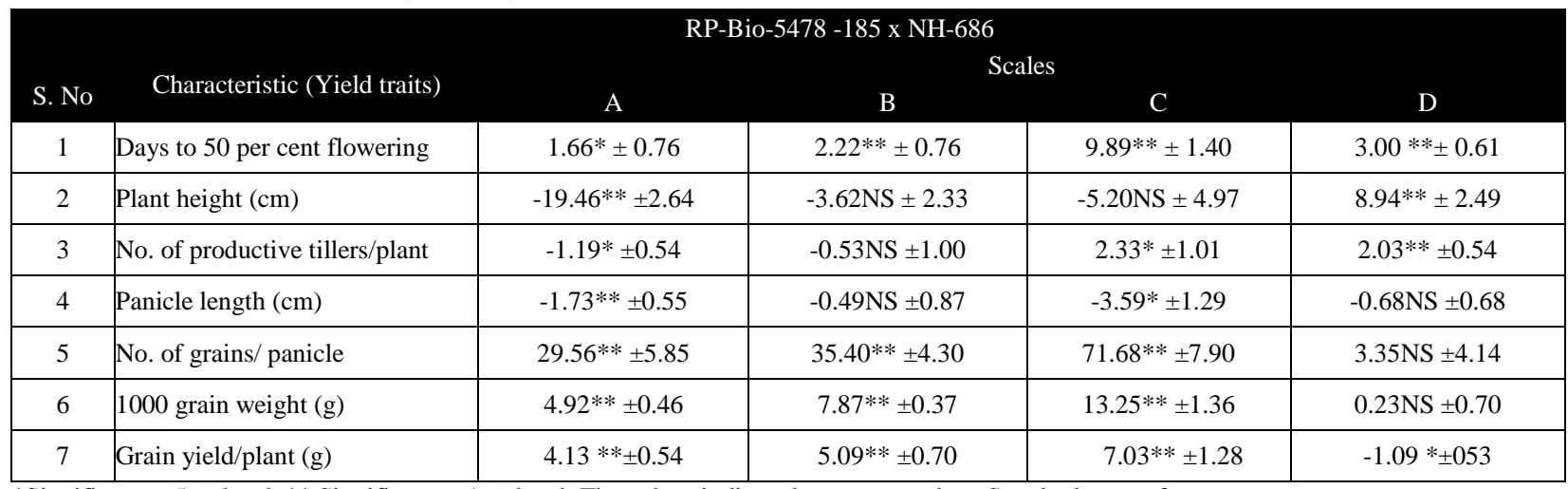

*Significant at $5 \%$ level, ** Significant at $1 \%$ level; The values indicated \pm corresponds to Standard error of mean

one of the scales (A, B, C \& D). Genetic components of variation estimated using Joint scale test presented in Table 4. As the Joint scaling test is a comprehensive test of simple additive - dominance model replacing A, B, C, D scaling test and involves weighted regression analysis, the components would be estimated and tested with more precision. Hence, a sequential method was followed to identify the best fit model in which the all the possible components would be significant and at the same time the $\chi^{2}$ test value becomes non significant. Major advantage of this test is that it can delete a non significant component in the sequential process and estimate the remaining significant components with maximum likehood precisions.

Initially, the genetic parameter ' $m$ ' was first used in the model. To find out if this adequately explained the variations in the trait and there was no need to proceed further to estimate any other genetical parameters, otherwise next higher parameters like $\mathrm{d}, \mathrm{h}$ etc., were introduced until $\chi^{2}$ test value became non significant (Kearsey \& Ponni, 1996). In present study, fortunately at least one component out of six was non significant, having at least one degree of freedom to facilitate the $\chi^{2}$ test. This procedure was adopted for three crosses uniformly and estimated the possible parameters by weighted least square method and discussed thoroughly.

For days to $50 \%$ flowering, a four parameter model was fitted in two crosses (MTU 1010 x NH-686 and WGL 32100 X RP-Bio5478-166) whereas in third cross, a two parameter model was sufficient to explain the genetic variation. Mostly dominance effects were significant, and in case of cross RP-Bio-5478-185 x $\mathrm{NH}-686$, the effects were in desirable negative sides. Significant interaction effects were observed for days to $50 \%$ flowering and [i] type was prevalent in desirable negative side in case of two crosses as early duration is preferable for rice crop, which is in agreement with the findings of Singh et al. (2007). With respect to the cross, MTU $1010 \times \mathrm{NH}-686$, the epistasis was of duplicate type, as [h] and [1] had opposite signs as was reported by Hasib et al. (2002), Prabhu et al. (2017) and Jondhale et al. (2018).

Significant estimates of ' $m$ ' were registered in all the three crosses with five parameters model. Highly significant dominance effects were noticed for this trait plant height which offers less scope for 
Table 4: Genetic components of yield \& yield attributing traits estimated through Joint scale test

\begin{tabular}{|c|c|c|c|c|c|c|c|c|}
\hline Cross & $\begin{array}{c}\text { Genetic } \\
\text { components }\end{array}$ & & & & Character & & & \\
\hline \multirow{7}{*}{$\begin{array}{c}\text { MTU } 1010 x \\
\text { NH-686 }\end{array}$} & & $\begin{array}{c}\text { Days to 50\% } \\
\text { flowering }\end{array}$ & $\begin{array}{l}\text { Plant height } \\
\text { (cm) }\end{array}$ & $\begin{array}{c}\text { No. of productive } \\
\text { tillers/ plant }\end{array}$ & $\begin{array}{c}\text { Panicle length } \\
(\mathrm{cm})\end{array}$ & $\begin{array}{c}\text { No. of grains } \\
\text { panicle }\end{array}$ & $\begin{array}{l}1000 \text { grain } \\
\text { weight (g) }\end{array}$ & $\begin{array}{c}\text { Grain yield/ } \\
\text { plant (g) }\end{array}$ \\
\hline & $\mathrm{m}$ & $88.12 * * \pm 0.26$ & $116.28 * * \pm 2.60$ & $16.86^{* * *} \pm 0.69$ & $23.19^{* *} \pm 0.30$ & $110.0^{* * * \pm 1.94}$ & $25.44 * * \pm 0.30$ & $22.48^{* *} \pm 0.44$ \\
\hline & [d] & - & - & $0.24^{*} \pm 0.47$ & & $4.72 * * \pm 1.67$ & $-0.73^{* * *} \pm 0.30$ & - \\
\hline & [h] & $26.94 * * \pm 1.05$ & $-22.17 * * \pm 6.26$ & $-24.82^{* *} \pm 2.09$ & $6.57^{* * *} \pm 1.08$ & $129.94 * * \pm 6.86$ & $-16.96^{* *} \pm 0.99$ & $-15.13^{* *} \pm 1.50$ \\
\hline & [i] & - & $-11.22^{* *} \pm 2.48$ & $19.07 * * \pm 1.73$ & - & - & - & \\
\hline & [j] & $1.35 \mathrm{NS} \pm 0.66$ & $5.42 * * \pm 1.35$ & $-5.10 * * \pm 0.51$ & $-6.96^{* * *} \pm 0.94$ & - & $6.18^{* *} \pm 0.69$ & - \\
\hline & [1] & $-24.12^{* *} \pm 1.0$ & $10.00^{*} \pm 3.77$ & $-0.35 * \pm 0.52$ & - & $-122.91 * * \pm 6.05$ & $16.66^{* * *} \pm 0.77$ & $14.84 * * \pm 1.23$ \\
\hline $\begin{array}{c}\chi^{2} \\
\text { value/probability }\end{array}$ & & $3.435 /(0.180) \mathrm{NS}$ & $\begin{array}{c}0.021 /(0.886) \\
\text { NS } \\
\end{array}$ & Nod.f & $\begin{array}{c}1.595 / \\
(0.660) \mathrm{NS} \\
\end{array}$ & $\begin{array}{c}3.33 / \\
(0.18) \mathrm{NS} \\
\end{array}$ & $3.293 /(0.070)$ & $4.39 /(0.222) \mathrm{NS}$ \\
\hline Model fitted & & 4 parameter & 5 parameter & 6 parameter & 3 parameter & 4 parameter & 5 parameter & 3 parameter \\
\hline Type of epistasis & & duplicate & duplicate & complementary & - & duplicate & duplicate & duplicate \\
\hline \multirow{6}{*}{$\begin{array}{c}\text { WGL-32100x } \\
\text { RP-Bio-5478-166 }\end{array}$} & $\mathrm{m}$ & $111.26^{* *} \pm 0.35$ & $102.93 * * \pm 0.48$ & $18.83 * * 1.56$ & $22.90 * * * 0.36$ & $209.15^{* *} \pm 5.37$ & $15.84 * * \pm 0.07$ & $19.46 * * \pm 0.24$ \\
\hline & [d] & $1.223^{* * *} \pm 0.21$ & $2.28^{* *} \pm 0.48$ & $1.83^{* *} \pm 0.08$ & - & - & - & - \\
\hline & [h] & - & $16.43 * * \pm 2.15$ & $-22.83^{* *} \pm 3.48$ & $1.53^{*} \pm 0.71$ & $-306.55^{* *} \pm 12.59$ & - & $-15.55^{* *} \pm 0.91$ \\
\hline & [i] & $-2.58 * * \pm 0.49$ & - & $-2.167^{* *} \pm 1.98$ & - & $-23.58 * * \pm 5.18$ & - & - \\
\hline & [j] & - & $-19.00^{* *} \pm 1.71$ & $-8.67^{* *} \pm 1.56$ & - & $-23.70 * * \pm 2.44$ & $2.60^{* * *} \pm 0.34$ & $2.47^{* *} \pm 0.70$ \\
\hline & [1] & $-3.23 \mathrm{NS} \pm 3.00$ & $-169.36^{* *} \pm 2.28$ & $15.66 * * \pm 0.34$ & - & $278.12 * * \pm 8.19$ & - & $17.10^{* * *} \pm 0.75$ \\
\hline $\begin{array}{c}\chi^{2} \\
\text { value/probability }\end{array}$ & & $1.196 /(0.550) \mathrm{NS}$ & $9.076 /(0.03) \mathrm{NS}$ & Nod.f & $\begin{array}{c}7.857 /(0.097) \\
\text { NS } \\
\end{array}$ & $0.490 /(0.484) \mathrm{NS}$ & $9.553 /(0.049)$ & $\begin{array}{c}3.414 /(0.181) \\
\text { NS } \\
\end{array}$ \\
\hline Model fitted & & 4 parameter & 5 parameter & 6 parameter & 2 parameter & 5 parameter & 2 parameter & 4 parameter \\
\hline Type of epistasis & & - & duplicate & duplicate & - & duplicate & - & duplicate \\
\hline \multirow{6}{*}{$\begin{array}{c}\text { RP-Bio-5478-185 } \\
\quad x \text { NH-686 }\end{array}$} & $\mathrm{m}$ & $99.08 * * \pm 0.56$ & $138.00 * * \pm 5.04$ & $14.02 * * \pm 0.90$ & $23.89 * * \pm 0.13$ & $117.62^{* *} \pm 1.64$ & $16.70^{* *} \pm 0.06$ & $14.0^{* * *} \pm 1.11$ \\
\hline & [d] & - & - & - & - & - & $0.81 \pm 0.06$ & - \\
\hline & [h] & $-5.19 * * \pm 0.77$ & $-75.54 * * \pm 11.80$ & $-10.41^{* *} \pm 2.40$ & - & $66.56^{* * *} \pm 6.54$ & $11.89^{* *} \pm 0.55$ & $13.52^{* *} \pm 2.58$ \\
\hline & [i] & $-4.80 * * \pm 0.70$ & $-17.88^{* * *} \pm 4.98$ & $-4.98 * * \pm 0.88$ & $1.42 * * \pm 0.18$ & - & - & $2.18^{*} \pm 1.07$ \\
\hline & [j] & - & $-8.76^{* *} \pm 2.63$ & - & - & $-69.43^{* *} \pm 6.45$ & $-2.93^{*} \pm 0.52$ & $-1.21 * \pm 0.48$ \\
\hline & [1] & - & $46.03 * * \pm 7.09$ & $7.27 * * \pm 1.64$ & - & - & $-12.85^{* *} \pm 0.62$ & $-11.44 * * \pm 1.61$ \\
\hline $\begin{array}{c}\chi^{2} \\
\text { value/probability }\end{array}$ & & $5.245 /(0.155) \mathrm{NS}$ & $\begin{array}{c}12.032 /(0.100) \\
\text { NS }\end{array}$ & $\begin{array}{c}3920(0.141) \\
\text { NS } \\
\end{array}$ & $\begin{array}{c}.229 /(0.376) \\
\text { NS } \\
\end{array}$ & $\begin{array}{c}1.206 /(0.752) \\
\text { NS }\end{array}$ & $\begin{array}{c}0.107 /(0.743) \\
\text { NS } \\
\end{array}$ & $\begin{array}{c}0.167 /(0.683) \\
\text { NS } \\
\end{array}$ \\
\hline Model fitted & & 2 parameter & 5 parameter & 4 parameter & 2 parameter & 3 parameter & 5 parameter & 5 parameter \\
\hline Type of epistasis & & - & duplicate & duplicate & - & - & duplicate & duplicate \\
\hline
\end{tabular}

direct selection. Significant interaction effects of all the three types [i], [j] and [1] indicated that epistasis, in addition to main effects played greater role in expression of this trait.

The fixable [i] type of interaction was observed to be prevalent in two crosses MTU 1010 x NH-686, RP-Bio-5478-185 x NH-686 in desirable side. Though the dominance $[\mathrm{h}]$ gene effects are highly significant, the existence of duplicate type to epistasis ( [h] and [1] in opposite signs viz., $+\&-$ ) would not permit development of heterotic hybrids or direct isolation of promising homozygous lines due to mutual cancellation of positive and negative effects of dominant gene. These findings are in accordance with the earlier reports of Hasib et al. (2002) and Dea et al. (2015).

The estimates indicated that the dominance gene effects $[\mathrm{h}]$ are more prevalent in comparison to the additive gene effects for productive tillers per plant. The fixable additive $\mathrm{x}$ additive type [i] gene action was also observed to be in undesirable negative side in two crosses. The additive $\mathrm{x}$ additive interaction effects [i] coupled with additive main effects [d] were positive in one cross, MTU 
$1010 \times \mathrm{NH}-686$, which indicated that selection would be possible for improvement of productive tillers in this one cross.

Significance of [h] type in one cross, RP-Bio-5478-185 x NH686 and [j] type in cross, MTU $1010 \times$ NH-686 for panicle length indicated that in biparental matings recurrent selection would be feasible to some extent in these two particular crosses. Verma et al. (2006) and Bano et al. (2017) also reported predominant role of dominant gene effects as in case of present study recommending recombination breeding by adopting bi parental mating or exploitation of heterosis for this trait, if possible.

For number of grains per panicle, failure of a simple additive dominance model indicated that, in addition to the main effect, the interaction effects also played greater role in expression of this important trait, particularly [1] type in MTU $1010 \mathrm{x} \mathrm{NH}-$ 686, [j] type in RP-Bio-5478-185 x NH-686 and all types in WGL-32100 x RP-Bio-5478-166. The estimates of dominance [h] effects are very high and highly significant in comparison to those of additive effects. In two crosses, the components due to additive effects are not significant. Naik et al. (2007), Kumar \& Mani (2010) also reported predominant role of non additive genetic effects. Dominance effects in expression of number of grains/panicle and duplicate type of digenetic interaction was observed for this trait through generation mean analysis as was reported earlier by Hasib et al. (2002), Kumar \& Mani (2010) and Subbalaxmi et al. (2016). Out of three crosses studied, two crosses viz., MTU $1010 \times$ NH-686, RPBio-5478- $185 \times$ NH-686 were found to be useful for heterosis breeding due to existence of higher magnitudes of dominance gene effects in positive side. However, in other crosses selection methods which improve this trait i.e number of grains per panicle through utilization of both additive and non additive gene action could not be ruled out.

For test weight, the analysis revealed the significance of the components ' $\mathrm{m}$ ' in all the three crosses at $1 \%$ level. Only two components ' $m$ ' \& [j] were significant in the cross, WGL-32100 x RP-Bio-5478-166 fitting in two parameter models, whereas other two crosses were fitted in 5 parameter digenic interaction models. This character was mainly governed by dominant gene effects viz., negatively in the cross, MTU $1010 \times \mathrm{NH}-686$ and positively in RPBio-5478-185 x NH-686 cross combination. Additive $x$ dominance [j] type interaction was also present in all the three crosses. Prevalence of duplicate epistasis [h] and [1] in opposite signs was in accordance with the findings of Verma et al. (2006), Naik et al. (2007), Subbalaxmi et al. (2016) and Muthu-vijayaragavan \& Murugan (2017). Prevalence of significant additive effects in the crosses viz., MTU $1010 \times$ NH-686 and RP-Bio-5478- $185 \times$ xH686 gives scope for direct selection and development of pure lines with higher test weight.
The analysis of genetical variation indicated that the final grain yield/plant was influenced by chiefly dominance genetic effects. These estimates were negative in two crosses and positive in one cross (RP-Bio-5478-185 x NH-686). Additive gene effects were not noticed in the expression of grain yield/plant. Maximum influence of dominant gene action for grain yield/plant was also identified by Banumathi \& Tygarajan (2005). Interaction, especially of dominance $\mathrm{x}$ dominance [1] type was prevalent and the $[\mathrm{h}]$ estimate were positive side in two crosses (MTU $1010 \mathrm{x}$ NH-686, and WGL-32100 x RP-Bio-5478-166), whereas negative in the remaining cross (RP-Bio-5478-185 x NH-686). Duplicate type of epistasis was found to be responsible for expression of this trait as was reported by Singh et al. (2007), Yadav et al. (2010), Gnanamalar \& Vivekanandhan (2013), Kumar et al. (2017), Jondhale et al. (2018). Existence of [i] type epistasis (fixable) in one cross i.e RP-Bio-5478-185 x NH-686, may offer a scope for direct selection to develop pure lines with good yield potentiality. However, keeping in view the governance of non additive gene action (dominance, additive $\mathrm{x}$ dominance and dominance $\mathrm{x}$ dominance ) in two crosses indicated some scope to develop selection programmes involving inter mating in early generations followed by selection to develop desirable genotype.

\section{Conclusions}

Generation mean analysis revealed that epistasis, in addition to main effects played greater role in expression of traits namely plant height and days to $50 \%$ flowering. The fixable [i] type of interaction was observed to be prevalent in two crosses MTU 1010 x NH-686, RP-Bio-5478-185 x NH-686 for plant height and WGL$32100 \times$ RP-Bio-5478-166, RP-Bio-5478-185 x NH-686 for days to $50 \%$ flowering in desirable side hence, can be used for selection. The interaction effects [i] coupled with additive main effects [d] were positive in one cross, MTU 1010 x NH-686, which indicated that selection would be possible for improvement of productive tillers in this one cross. Failure of a simple additive - dominance model indicated that, in addition to the main effect, the interaction effects also played greater role in expression of this important trait, particularly [1] type in MTU $1010 \times \mathrm{NH}-686$, [j] type in RP-Bio5478-185 x NH-686 and all types in WGL-32100 x RP-Bio-5478166. 1000 grain weight was mainly governed by dominant gene effects viz., negatively in the cross, MTU $1010 \times$ NH-686 and positively in RP-Bio-5478-185 x NH-686 cross combination. Additive $\mathrm{x}$ dominance [j] type interaction was also present in all the three crosses. Prevalence of significant additive effects in the crosses viz., MTU $1010 \times$ NH-686 and RP-Bio-5478- 185 x NH686 gives scope for direct selection and development of pure lines with higher test weight. For grain yield per plant, interaction, especially of dominance $\mathrm{x}$ dominance [1] type was more prevalent and the $[\mathrm{h}]$ estimates were positive side in two crosses (MTU 1010 $x$ NH-686, and WGL-32100 x RP-Bio-5478-166), whereas 
negative in the remaining cross (RP-Bio-5478-185 x NH-686). Duplicate type of epistasis was found to be responsible for expression of grain yield per plant.

The Generation mean analysis indicated the presence of epistasis in expression of grain yield and its components. The interaction was of duplicate epistasis, therefore, in addition to the main genetic effects, ([d], [h] components), the interaction components would also have to be taken into consideration to develop the breeding strategy. Prevalence of significant additive effects in the crosses MTU1010 x NH-686, RP-Bio-5478-185 x NH-686 indicated effectiveness of direct selection for improvement.

\section{Acknowledgement}

The First author gratefully acknowledges Dr. N. Sarla, National professor (Crop Improvement), ICAR-IIRR, Hyderabad for providing the parent material for crossing work.

\section{Conflict of Interest}

Authors would hereby like to declare that there is no conflict of interests that could possibly arise.

\section{References}

Bano DA, Singh SP, Waza AS (2017) Generation Mean Analysis for Yield and Quality Traits in Aromatic Genotypes of Rice (Oryza sativa L.). International Journal of Pure and Applied Bioscience 5: 870-878.

Banumathy S, Thiyagarajan K (2005) Genetic analysis of yield traits in rice. Crop Research 30: 202-207.

Cavalli LL (1952) An analysis of linkages of quantitative inheritance. In: Revie ECR \& Waddington CH (Eds.)Quantitative Inheritance, HMSO, London Pp.135-144.

Dea MY, Moussa S, Ibnou D, Nasser YK, Adam A (2015) Generation mean analysis to estimate genetic parameters of some traits for rice-weed competitiveness. Journal of Plant Breeding and Crop Science 7: 163-169.

Gnanamalar RP, Vivekanandhan P (2013) Genetic architecture of grain quality characters in rice (Oryza sativa L.). European Journal of Experimental Biology 3: 275-279.

Hasib KM, Ganguli PK, Kole PC (2002) Genetic analysis of some quantitative characters in aromatic rice involving induced mutants. Tropical Agricultural Research and Extension 5: 1-6.

Hayman B (1958) The separation of epistatic from additive and dominance variation in generation means. Heredity 12: 371-390.

Jinks JL, Jones RM (1958) Estimation of the components of heterosis. Genetics 43: 223-34.
Jondhale AS, Bhave SG, Jogi SR (2018) Genetic evaluation of quantitative traits of rice (Oryza sativa L.) by generation mean analysis. Journal of Pharmocognasy and Phytochemistry 1: 2477-2480.

Mather K (1949) Biometrical Genetics. Metuen and Co. Ltd., London.

Kearsey M, Ponni H (1996) The Genetic analysis of quantitative traits. Chapman and Hall. London, U.K.

Kumar A, Mani SC (2010) Gene action for grain yield, its components and quality traits in Basmati rice (Oryza sativa L.). Pantnagar Journal of Research 8: 26-31.

Kumar PS, Saravanan K, Sabesan T (2017) Generation mean analysis for yield and grain quality characters in rice (Oryza sativa L.). Plant Archives 17: 557-560.

Muthu- vijayaragavan R, Murugan E (2017) Generation Mean Analysis for Yield and Salinity Tolerance in Rice (Oryza sativaL.). International Journal of Current Microbiology and Applied Sciences 6: 2249-2257.

Naik R, Sreenivasulu Reddy P, Ramana JV, Srinivasa Rao V (2007) Correlation and Path Coefficient Analysis in rice (Oryza sativa L.). The Andhra Agricultural Journal 52: 52-55.

Prabhu SM, Meenakshi Ganesan N, Jeyaprakash P, Selvakumar R, Prabhakaran NK (2017) Generation mean analysis for yield and its contributing characters in F2 populations of rice (Oryza sativa L.). International Journal of pure and applied biosciences 5: 373-380.

Singh NK, Singh PK, Singh ON, Singh S, Dwivedi JL, Giri SP, Tiwari $T$ (2007) Gene effects and selection parameters in rainfed low land rice. Oryza 44: 291-285.

Subbulakshmi K, Shunmugavalli N, Muthuswamy A (2016) Generation mean analysis for yield and quality traits in $\mathrm{F}_{2}$ and $\mathrm{F}_{3}$ generation of rice (Oryza sativa L.). Electronic Journal of Plant Breeding 7: 491-495.

Uzokwe VNE, Asafo Adjei B, Fawole I, Abaidoo R, Odeh IOA, Ojo DK, Dashiell K, Nteranya Sanginga N (2017) Generation mean analysis of phosphorus use efficiency in freely nodulating soybean crosses grown in low phosphorus soil. Plant Breeding 136: $139-146$.

Verma RS, Yadav RD, Giri P (2006) Genetics of yield and its important components in rice (Oryza sativa L.). Crop Research 31: 142-146.

Yadav SK, Suresh BG, Pandey P, Kumar B (2010) Assessment of yield and grain quality characters of rice grown in coastal saline low land of Tamilnadu. Electronic Journal of Plant Breeding 1: 56-59. 